\title{
Agnieszka Sojka, Człowiek i Bóg w pieśni. Studium antropologiczno- pedagogiczne, Wydawnictwo Uniwersytetu Jagiellońskiego, Kraków 2008, ss. 112.
}

Pieśń jest jedną z tych ludzkich aktywności, które podobnie jak poezja, malarstwo czy architektura stanowią świadomy wytwór człowieka zwany kulturą. Wydaje się jednak, że jednocześnie należy do tych zjawisk w obrębie kultury, których potencjał badawczy nie jest w dostatecznej mierze realizowany. Z pewnością badania nad pieśniami nie są prowadzone $\mathrm{w}$ takim stopniu, jak na przykład nad poezją czy literaturą piękną. Można zaryzykować twierdzenie, że jest ona kategorią niedocenianą.

Lukę w tych badaniach próbuje wypełnić książka Agnieszki Sojki pod tytułem: Człowiek i Bóg w pieśni. Studium antropologiczno-pedagogiczne. Pozycja ta ukazała się w Wydawnictwie Uniwersytetu Jagiellońskiego i stanowi część pracy doktorskiej Autorki, która w swej pracy naukowej zajmuje się antropologicznymi oraz aksjologiczno-wychowawczymi kontekstami wytworów kultury.

Badania nad pieśnią można prowadzić z różnych perspektyw: semantycznej (m.in. wskazanie znaczeń terminów zawartych w tekstach), historycznych (m.in. pokazujących uwarunkowania i historyczny kontekst powstania pieśni), antropologiczno-filozoficznej (wskazujące na założenia filozoficzne zawarte w materiale badawczym) czy pedagogicznej (których celem jest wskazanie wychowawczych kontekstów danych zjawisk). Autorka wybrała drogę analizy w perspektywie antropologiczno-pedagogicznej; należy jednak zaznaczyć, że nie zrezygnowała jednocześnie z innych perspektyw (na przykład analizując strukturę, pragmatykę językową pieśni czy też pieśń jako akt komunikacji).

Zasadniczym celem, jaki postawiła przed sobą Autorka, był opis i rekonstrukcja koncepcji człowieka, Boga oraz świata wartości zawartego w wybranych pieśniach. Do osiągnięcia tak zdefiniowanego celu posłużyła się metodą fenomenologiczną (opisem istotnościowym). Zdecydowała się zatem na metodę, która w dużym skrócie polega na specyficznie intuicyjnym wglądzie w dane zjawisko (w to, co badane) i której zadaniem jest odsłonięcie fenomenu, istoty, w tym przypadku - pieśni. Analizie takiej zostało poddane 2 tysiące pieśni religijnych, powstałych w okresie od 1945 roku do końca XX wieku. Wskazany wyżej cel realizowany jest w pięciu rozdziałach.

W rozdziale pierwszym, który nosi tytuł: Humanistyczno-fenomenologiczna perspektywa badań nad pieśnia zostajemy wprowadzeni w kontekst prowadzonych badań. Zostaje między innymi przedstawiona charakterysty- 
ka materiału badawczego, modele komunikacji i struktury komunikacyjnej pieśni oraz uzasadnienie dla przyjętej metody analizy fenomenologicznej.

W rozdziale drugim Fenomen pieśni - istota, wartości i możliwości badawcze, w którym pokazane są możliwości badawcze, jakie stoją przed analizowanym tu przedmiotem, Autorka rozważa kolejno: interdyscyplinarny charakter badań nad pieśnią, antropologiczno-aksjologiczne motywy pieśni, pieśń jako akt komunikacji, specyfikę języka oraz typy sytuacji nadawczych i odbiorczych pieśni.

Człowiek i Bóg - nadawca i odbiorca w strukturze tekstów pieśni to rozdział kolejny (trzeci), w którym podejmowana jest próba określenia koniecznej do komunikacji przestrzeni wartości (przestrzeni aksjologicznej). Autorka analizuje rolę nadawcy i odbiorcy oraz kod językowy (kontekst światopoglądowy), jaki odnaleźć możemy w komunikacie, jakim jest pieśń. Jest to zarazem próba wydobycia świata wartości założonego w analizowanym materiale badawczym.

Koncepcja Boga i człowieka wyinterpretowana z pieśni ukazana jest w rozdziale czwartym, noszącym tytuł: Aksjologiczno-antropologiczny wizerunek czlowieka i Boga w pieśni. Przedstawione są tu również rodzaje i hierarchie wartości, jakie odnaleźć można w tych koncepcjach. Zagadnienia te podejmowane są w podrozdziałach: Człowiek podmiotem sprawczych działań - filozoficzne myślenie o człowieku, Homo religiosus - pielgrzym dookreślony oraz Bóg w czlowieku - czlowiek w Bogu.

W rozdziale ostatnim $W$ strone wychowania człowieka, Autorka podejmuje problem wychowawczych implikacji zawartych w pieśniach koncepcji Boga, człowieka oraz świata wartości. Pieśń, jak każdy wytwór kultury, jest przekaźnikiem konkretnych wartości; w tej części znajdziemy próbę odpowiedzi między innymi na pytanie o to, jaką wychowawczą rolę pełnią i mogą pełnić te wartości, ale też w jaki sposób pieśn może być wykorzystywana w praktyce pedagogicznej.

Książka zasługuje na uwagę nie tylko ze względu na poddany analizie, bardzo liczny materiał badawczy, jak i analizy strukturalno-językowe pieśni, ale przede wszystkim ze względu na ciekawe i wartościowe badania fenomenologiczne. Ukazują one pieśń, po pierwsze, jako świadectwo zmagania człowieka z transcendencją, próbę jej oswojenia i odnalezienia języka porozumienia $\mathrm{z}$ bóstwem, po drugie jako źródło, w którym odnaleźć możemy wielość koncepcji światopoglądowych na temat człowieka i Boga, i po trzecie, pokazują pieśń jako potencjalny materiał zarówno dla analizy jak i praktyki pedagogicznej.

Autorka nie uniknęła jednak pewnych błędów; niewiele miejsca poświęciła na rozwinięcie problemu praktyczno-pedagogicznych implikacji swoich badań. Relatywnie wiele poświęcono badaniom filozoficzno-analitycznym, 
a mało pedagogicznym. Pedagog-praktyk szukający wskazówek co do tego, jak wykorzystywać pieśni w swojej pracy wychowawczej, niewiele ich tu odnajdzie. Innym, mniejszym brakiem, jest nadmierna powierzchowność w prezentacji niektórych zagadnień filozoficznych. Dotyczy to przede wszystkim problematyki wartości.

Podsumowując, w książce Człowiek i Bóg w pieśni. Studium antropologiczno-pedagogiczne A. Sojka w dużym stopniu wywiązała się z postawionego przed sobą zadania. Omawiana pozycja jest twórczą i, pomimo pewnych braków, udaną próbą stosowania metody fenomenologicznej w pedagogice i w badaniach nad wytworami kultury.

Tomasz Leś*

\section{Mirosław Wierzbicki, Nauczyciel w szkole salezjańskiej, Wydawnictwo Salezjańskie, Warszawa 2011, ss. 260.}

Publikacja pt. Nauczyciel w szkole salezjańskiej, której autorem jest ks. Mirosław Wierzbicki SDB ${ }^{1}$, ukazała się nakładem Wydawnictwa Salezjańskiego w 2011 roku. Problematyka pracy ma swoje podstawy w działalności księdza Jana Bosko, zapoczątkowanej w 1841 roku we Włoszech. Praca edukacyjna podjęta przez tego wychowawcę z Turynu miała na celu nie tylko wychowywanie dobrego chrześcijanina, ale i uczciwego obywatela, za pomocą metody zwanej systemem prewencyjnym.

Jak stwierdza autor pracy, główną inspiracją dla powstania książki był rozwój niepublicznego szkolnictwa katolickiego. Nie bez znaczenia był również fakt, że ks. M. Wierzbicki jest członkiem Towarzystwa Salezjańskiego, oraz to, że od początku pobytu w tym zgromadzeniu zakonnym miał kontakt ze szkołą, sam był nauczycielem i zajmuje się wychowaniem młodzieży w Polsce i za granicą. Warto podkreślić też fakt, że w dotychczasowej literaturze polskiej można odnaleźć stosunkowo niewiele prac traktujących o nauczycielu szkoły salezjańskiej.

* Mgr Tomasz Leś - doktorant w Instytucie Pedagogiki Uniwersytetu Jagiellońskiego w Krakowie, magister pedagogiki i filozofii na UJ.

${ }^{1}$ Ks. dr Mirosław Wierzbicki SDB - salezjanin, posiada wieloletnie doświadczenie pedagogiczne w Polsce i za granicą. Wychowawca i nauczyciel w wielu salezjańskich ośrodkach wychowawczych. Stopień doktora uzyskał na Uniwersytecie Mikołaja Kopernika w Toruniu w roku 2009. Od 2011 roku wykładowca na Wydziale Nauk o Wychowaniu Papieskiego Uniwersytetu Salezjańskiego w Rzymie. 